\title{
Implementation of Article 7 Law 16 Year 2019 Concerning Amendments to Law 1 Year 1974 Concerning Marriage with the Age Limit of Marriage in Sidatape Village
}

\author{
Dewa Gede Sudika Mangku${ }^{1}$, I Made Yudana ${ }^{2}$ \\ \{dewamangku.undiksha@gmail.com ${ }^{1}$, madeyudana@undiksha.ac.id ${ }^{2}$ \} \\ Universitas Pendidikan Ganesha, Indonesia ${ }^{1,2}$
}

\begin{abstract}
The problems discussed in this thesis are how to implement the minimum age limit in marriage according to Law Number 1 of 1974 and whether the factors that become obstacles in implementing the minimum age limit in marriage in accordance with Law Number 1 of 1974. The method used in the study This is a juridical empirical, with qualitative descriptive research specifications. The data collected are primary data and secondary data. Primary data were obtained from observations and interviews with predefined respondents. The results of this study indicate that from 2016 to 2020 there were still many underage marriages that occurred in Sidetapa Village, Banjar District. This marriage was caused due to economic problems in the family, which resulted in underage marriages. Lack of socialization about the marriage law in Sidetapa village is one of the inhibiting factors in the community to understand the aw.
\end{abstract}

Keywords: Marriage, Underage, Sidetapa Village, Buleleng.

\section{Introduction}

Marriage is a physical and mental bond between a man and a woman as husband and wife with the aim of forming a happy and eternal family (household) based on God Almighty (Law No.1 of 1974). Meanwhile, the definition of marriage according to Burgerljik Wet Boek (Dutch heritage) is a relationship that is only civil in nature. This means that marriage is an "agreement" or "agreement" between individuals that is not related to the religious-magical element. Marriage is considered legal and legal if it has been agreed upon and approved by each party and is recorded in the form of a marriage certificate at the civil registry office [1].

Humans by nature have the instinct to maintain their life by obtaining offspring. To get offspring is done by marriage. Marriage is one of the important parts in human life that is sacred and holy, where two people of different sexes, namely men and women are brought together with conditions and laws that apply to the same purpose, namely to form a family in the long term. Unlimited time and is valid for a lifetime. Article 1 of Law Number 1 Year 1974 states that marriage is a physical and spiritual bond between a man and a woman as 
husband and wife, which aims to form a happy and eternal family based on the One Godhead. Marriage is generally motivated by a sense of mutual love and belonging to each other, this feeling that encourages someone to commit to marriage [2].

Marriage is a sacred and special event, where the marriage is generally carried out once in a lifetime. Based on this, most people pay a lot of money to carry out a marriage ceremony that lasts only a few days. Seeing this fact, it can be said that marriage is a very important event in human life. Because marriage is a very important event, marriage in Indonesia has been regulated in such a way both in religion, customs and state law. To ensure legal certainty and legal unification in the field of marriage, the national law on marriage is regulated by Law Number 1 of 1974 concerning Marriage, hereinafter referred to as the Marriage Law [3].

Marriage is the initial gateway to forming a family which is the smallest unit of a society. The family which is the smallest unit of society consists of husband and wife, or husband and wife and their children, or father with child, or mother with child. The purpose of marriage is not limited to biological relationships. Marriage has a further purpose than that, which includes a loving life guidance so that people can live peacefully in family and society. To achieve the noble goal of marriage, of course, the prospective bride and groom must have entered her body and soul before marrying. This maturity is expected to realize the goal of marriage well without thinking about divorce and to get good and healthy offspring [4].

In discussing maturity, we cannot limit ourselves to only one or two scientific fields, but we are forced to carry out interdisciplinary studies because maturity itself is used by almost all fields of social science, including: sociology, law, political science In economics, even in religious studies, issues of maturity are fundamental and decisive. In the field of law, maturity can determine the validity of a legal act. An immature person is seen as a subject who has not been able to act alone before the law, so that his legal action must be represented by his parents / guardians [5].

Diversity in determining the age limit for maturity is caused by the absence of a standard that can be used accurately to determine the limit of human maturity. Age and the act of marriage can indeed be one of the determinants of maturity. But it is not always the right measure because maturity itself is a condition in which a person has reached the maturity level in thinking and acting, while the maturity level is present in each person differently, there is even an opinion that it is possible until the end of human life. never experience maturity because maturity is not always proportional to age. Indeed, not all laws and regulations explicitly state limits on maturity [6].

However, by determining the age limit for a certain legal act, it is actually the maturity factor that is being measured. For example, some laws only state the age limit for those who are called children, so that those above the age limit must be considered as an adult, or the law allows a person to commit certain acts after exceeding the specified age limit. All these arrangements are ultimately focused on the meaning and understanding of maturity. The ability to think conceptually based on norms and value systems makes human civilization continue to develop rapidly. In relation to the pattern and level of human civilization, there is a condition in humans which is always associated with mental qualities and personal maturity, this condition is none other than adulthood. Maturity is always a measure in every action and 
responsibility that is carried out, so that maturity is a very important factor in every social interaction, whether it has legal consequences or is limited to the scope of public relations [7].

In almost every area of life, maturity is always a measure of the responsibility of an act. This is because only a person who is an adult is deemed to be perfectly accountable for his actions, this can be seen from several legal provisions which qualify for actions which in principle can only be done by those who are adults. But on the other hand, there is a phenomenon of underage marriage which is quite interesting to the attention of various circles, this happens because in fact the phenomenon of underage marriage is like an iceberg phenomenon that looks a little above it, even though in the plains the fact is very much happening in Indonesian society [8].

This underage marriage raises many social problems and on the other hand also creates legal problems. The controversy over underage marriage has become a debate, especially regarding the minimum age limit for a child to marry. So far, what has happened is an intersection between the two legal systems, namely Islamic law and national law, especially those which each regulate marriage and the rights of the child as the subject of the marriage.

Article 1320 of the Civil Code states that one of the conditions for the validity of the agreement is that if the legal subject is capable of acting, the meaning of capable of acting is closely related to the meaning of maturity, because according to Article 1330 point 1 of the Civil Code, one of the people who are not capable of acting is those who are not yet mature. The marriage law also requires a maturity limit as stated in Article 7 of Law 16 of 2019 concerning Amendments to Law 1 of 1974 concerning Marriage that "Marriage is only permitted if the male has reached the age of 19 (nineteen) years and the woman has reached the age of 19 (nineteen) years [9].

Based on the above background, the researcher is interested in raising the title of research on "Implementation of the Implementation of Article 7 of Law 16 of 2019 concerning Amendments to Law 1 of 1974 concerning Marriage with Respect to the Age Limit of Marriage in Sidatape Village".

\section{Method}

This research is a descriptive study which aims to describe something in a certain area and at a certain time. The meaning here is to describe in detail and critically examine legal facts related to the application of Article 7 of Law 16 of 2019 concerning Amendments to Law 1 of 1974 concerning Marriage with regard to the Age Limit of Marriage in Sidatape Village.This research took place in Buleleng Regency, Bali, especially in the village of Sidatape. In Sidapate Village, many of them perform early marriages. In addition, it is also interesting to study and research related to the Application of Article 7 of Law 16 of 2019 concerning Amendments to Law 1 of 1974 Concerning Marriage with Respect to the Age Limit of Marriage in Sidatape Village [10].

In this study, primary data and secondary data were used. Primary data were collected through observation and interviews. Secondary data is collected through literature / document 
studies, namely on legal materials that are relevant to the research problem. This research method is carried out in the form of previous studies, textbooks, related news in print media, as well as online data search on the internet. And this method is very useful because it does not interfere with the object of research or the atmosphere of research [1].

This research is descriptive in nature, so the sampling technique used is non-probability sampling, meaning that in this study there is no definite rule on how many samples must be taken in order to represent the population. Data processing and analysis techniques in this study will be carried out qualitatively. All data from the research results were collected both from primary data and secondary data, processed and analyzed by systematically compiling the data. The data that has been compiled are linked between one data and another, then interpreted to understand the meaning of the whole data. The analysis process continues since the search for data in the field and continues until the analysis stage [11] .

\section{Result and Discussion}

Underage marriage can be defined as a marriage that is carried out by a person who has not entered the age of marriage. Underage marriage is not something new, and it can be legal to implement, but by fulfilling certain requirements, as stipulated in Law No.1 of 1974 concerning Marriage. Therefore, it can be said that underage marriage is a marriage which according to law cannot be practiced freely. In view of the law, underage marriage is something that can have an impact, as stated in the explanation of article 7 paragraph (1) of Law No.1 of 1974, namely: "to maintain the health of husband and wife and their offspring, it is necessary to set an age limit. for marriage ". If interpreted again, according to the law it is clear that the impact of this underage marriage can be felt in the next family life, which can be said to have a negative impact [2].

The realities of the pros and cons of underage marriage have yet to find a solution. The main factor that makes this problem drag on is the lack of understanding between the two factions that have different views. The group that agrees has the ambition to defend their right to marry a minor by reason of worship, has the consent of the parents of the child they want to marry, and several other alibis that are used as supporters without paying attention to the child's main interests or rights. The group that prohibits the marriage of minors is trying to fight for the rights that should be obtained by children [3].

When viewed from the socio-economic aspect, this marriage is labeled as causing problems in terms of child protection, because in the real situation in society, this marriage is often used as an excuse for parents to exploit in order to meet the economic needs of the family. In addition, if the child is the woman, it can be said that the marriage of minors has neglected and even degraded the status and dignity of women. The impact of this marital behavior causes sexual trauma and has a negative impact on reproductive health in girls. Mentally, psychologically, the child also feels unable to make the right decision for himself to bear the responsibility of taking care of household life which should be for people who are old enough or mature. In addition, for the child, unconsciously there are many negative effects that will arise due to this marriage, ranging from limited relationships to the loss of playing time with peers which has an impact on the child's mental and emotional development [4]. 
Regarding the determination of age in marriage according to Law no. 1 of 1974 can be concluded in article 7 paragraphs 1 and 2, namely as follows: a. Marriage is only permitted if the male has reached the age of 19 and the female has reached the age of $16 . \mathrm{b}$. In case of deviation from paragraph (1) of this article, dispensation may be requested from the court or other official appointed by the parents of the woman. In the Civil Code, it has been explained in article 29, namely as follows: "A boy who has not reached the age of 18, like a girl who has not reached the age of fifteen, is not allowed to bind herself in marriage" [5].

Meanwhile, in the presence of important reasons, the president is in power to remove this prohibition by giving dispensation. The provisions regarding dispensation in this article are no longer valid. As stated in the explanation of article 7 paragraph (2) of Law no. 1 of 1974 the dispensation provisions governing the granting of dispensation to marriage as regulated in the Civil Code are no longer valid with the enactment of Law No. 1 of 1974 concerning Marriage. In law no. 1 of 1974 concerning marriage, stipulates that the determination of the age limit of 19 years for men and 16 years for women to be able to get married is based on physical maturity (physical), spiritual maturity, or psychological (psykhis) [7].

So it is hoped that a man and woman at this age limit are able to understand the consequences of direct marriage and have the responsibility to be able to foster a happy family, in accordance with the goals expected by the marriage law. Marriage is not only a physical bond but also an inner bond between husband and wife in a happy and eternal community of life. The age of marriage is also related to the maturity of the husband and wife, within that age limit, it can be implemented properly, in fostering family welfare, and in their social interactions [7].

In the Civil Code, the determination of age in a marriage, if we compare it to the provisions in Article 29 of the Civil Code, is for men 18 years and for women 15 years. The measure to determine the age limit in the Civil Code is based solely on the biological function of a man and a woman. Where at the age limit a person is considered mature to be married, so that if they get married it is expected that from that marriage a child can be born. The basis for determining the age in marriage can be said to be based solely on one's physical maturity or one's biological function [6].

The results of the research carried out in Sidetape Village, Bajar Subdistrict, still have underage marriages (early marriage), this is based on the data that has been collected. The data above shows that from 2016 to 2020 there are still underage marriages. If we describe one by one in 2016 there were 23 marriages in Sidetapa village as well as in 2020. The data obtained shows that underage marriages still occur. The practice of early marriage is often influenced by local traditions. Although there are statutory provisions prohibiting early marriage, it turns out that there are also dispensation facilities. The Religious Courts and the Office of Religious Affairs often grant dispensations if the bride is found to be a minor.

Child protection is all activities to guarantee and protect children and their rights so that they can live, grow, develop, and participate optimally in accordance with human dignity, and receive protection from violence and discrimination. So, what is protected is that all children, including children who are in conflict with the law. As for the purpose of child protection, it is for the realization of Indonesian children who are qualified, have noble character, and are prosperous. Based on the explanation regarding child protection, it can be concluded that in the context of the nation and state, children are an immeasurable asset of wealth, with the existence of the Child Protection Law it is hoped that it can provide security and comfort for the growth and development of children in the community to avoid the threat of crime and all kinds this exploitation and protection is guaranteed by the government and the state. Factors that become obstacles in implementing the minimum age limit in marriage in accordance with 
Article 7 of Law Number 16 of 2019 concerning Amendments to Law Number 1 of 1974 concerning Marriage [9].

The results of the interviews that the researchers have conducted are obstacles in implementing the minimum age limit in marriage in accordance with Article 7 of Law Number 16 of 2019 concerning Amendments to Law Number 1 of 1974 concerning Amendments to Law Number 1 of 1974 concerning Marriage still Village officials and the community in Sidetape Village have not implemented this. This is closely related to the past history in the village of Sidetapa, Banjar District.

The various impacts of early marriage or underage marriage can be stated as follows: First, Biological impact; Biologically, their reproductive organs are still in the process of maturing so they are not ready to have sex with the opposite sex, especially if they become pregnant and then give birth. If it is forced, it will result in trauma, extensive tearing and infection that will endanger the reproductive organs to the point of endangering the lives of children. It is questionable whether such sexual relations are based on equality in reproductive rights between wife and husband or whether there is sexual violence and coercion (manipulation) of a child. Second, Psychological impact; Psychologically, the child is also not ready and understands about sexual relations, so it will cause prolonged psychological trauma in the child's psyche that is difficult to heal. The child will be gloomy and regret his life which ended in a marriage that he himself does not understand the decision of his life. In addition, the marriage bond will eliminate the child's right to education (fair 9 years), the right to play and enjoy his spare time and other rights inherent in the child [8] .

ThirdSocial impact, this social phenomenon is related to socio-cultural factors in a patriarchal society that is gender biased, which places women in a low position and is only considered a complement to male sex. This condition is very contrary to the teachings of any religion, including Islam, which respects women very much (Rahmatan lil Alamin). This condition will only preserve a gender-biased patriarchal culture which will lead to violence against women.Fourth, Impact of deviant sexual behavior. The existence of deviant sexual behavior, namely behavior that likes to have sex with children is known as pedophilia. This act is clearly an illegal act (using child sex), but is packaged as if marriage becomes legal. This contradicts Law No. 23 of 2002 concerning Child Protection, particularly Article 81, the threat of imprisonment for a maximum of 15 years, a minimum of 3 years and a maximum fine of 300 million and a minimum of 60 million rupiah. If legal action is not taken against people who use child sexuality illegally, it will cause no deterrent effect from the perpetrator and will even become an example for others [7].

\section{Conclusion}

Implementation of the Minimum Age in Marriage in accordance with Article 7 of Law 16 of 2019 concerning Amendments to Law 1 of 1974 concerning Marriage that occurred in the village of Sidetapa, Kecmatan Banjar from 2016 to 2020, there are still underage marriages (pre-wedding early). This is because economic factors and knowledge of the law of marriage in the village of Sidetapa are still very minimal, this is what causes the implementation of the marriage law to not work properly. The factors that become obstacles in implementing the minimum age limit in marriage according to Article 7 of Law Number 16 of 2019 concerning 
Amendments to Law Number 1 of 1974 concerning Marriage are related to the economic factors of the community in Sidetapa Village, Banjar District, because with how to give "permission" for early marriage. Parents feel they have let go of their burden and no longer have the responsibility to send them to school. Implementation of Minimum Age in Marriage in accordance with Article 7 of Law 16 of 2019 concerning Amendments to Law 1 of 1974 concerning Marriage that occurred in the village of Sidetapa, Kecmatan Banjar is still very minimal, this is the need for village officials to continue to provide social assistance related to The purpose of the marriage law is to provide legal education to the community in Sidetapa village. The role of government agencies and the family in particular is very much needed to provide education to children and the community, especially in rural communities, that marriage at the age of a child greatly impacts the psychological and psychological development of the child concerned and can hinder children from achieving their goals want, therefore it is hoped that the community and related institutions can work together to support each other so that child marriages can be reduced and do not happen again.

\section{References}

[1] A. Ali and W. Heryani, Exploring the Empirical Study of Law (in Bahasa). Jakarta: Kencana Prenada Media Group, 2012.

[2] S. Blackburn and S. Bessell, "Marriageable age: Political debates on early marriage in twentieth-century Indonesia," JSTOR Indones., vol. 63, pp. 107-141, 1997, [Online]. Available: https://www.jstor.org/stable/3351513 .

[3] A. M. Buttenheim and J. Nobles, "Ethnic diversity, traditional norms, and marriage behaviour in Indonesia,” Popul. Stud. (NY)., vol. Vol.63, no. 3, pp. 277-294, 2009, [Online]. Available: https://doi.org/10.1080/00324720903137224.

[4] B. Hermanto and I. G. Yusa, "Children Rights and the Age Limit: The Ruling of The Indonesian Constitutional Court," Kertha Patrika, vol. 40, no. 2, pp. 61-70, 2018, doi: https://doi.org/10.24843/KP.2018.v40.i02.p01.

[5] H. Horii, "Pluralistic legal system, pluralistic human rights?: teenage pregnancy, child marriage and legal institutions in Bali," J. Leg. Plur. Unoff. Law, vol. Vol. 51, no. No.3, pp. 292-319, 2019, [Online]. Available: https://doi.org/10.1080/07329113.2019.1683429.

[6] D. G. S. Mangku and N. P. R. Yuliartini, "Diseminasi Undang-Undang Nomor 1 Tahun 1974 Tentang Perkawinan Dalam Peningkatan Kesadaran Hukum Masyarakat Di Desa Sidetapa Terkait Urgensi Pencatatan Perkawinan Untuk Memperoleh Akta Perkawinan.," J. Pendidik. Kewarganegaraan Undiksha, vol. Vol. 8, no. No. 1, pp. $138-155,2020$.

[7] A. Utomo and P. McDonald, "Who marries whom?: Ethnicity and marriage pairing patterns in Indonesia," Asian Popul. Stud., vol. Vol. 12, no. No. 1, pp. 28-49, 2016.

[8] M. H. Withers, P. Tavrow, and N. A. Adinata, "Do ambivalent women have an unmet need for family planning? A longitudinal study from Bali, Indonesia," Women's Heal. issues, vol. Vol. 12, no. No. 6, pp. 444-449, 2011.

[9] Undang-Undang Republik Indonesia, "Undang-undang (UU) tentang Perubahan atas Undang-undang Nomor 1 Tahun 1974 tentang Perkawinan," hukumonline.com, 2019. .

[10] M. Abdurrahman, Sociology and Legal Research Methods (in Bahasa). Malang: 
UMM Press, 2009.

[11] J. Ibrahim, "Teori \& Metodologi Penelitian Hukum Normatif," Teor. Metodol. Penelit. a., 2006. 